\title{
HEALTH AND ENVIRONMENTAL CONDITIONS IN THE IRON FOUNDRY
}

\author{
BY \\ G. F. KEATINGE and N. M. POTTER \\ From the Medical Department, The Butterley Company, Derby
}

This survey is largely based on experience gained in the foundries of the Butterley Company. Number 1 Foundry produces small, medium and light castings on a semi-mechanized basis. and very light castings on a fully mechanized unit, while Number 2 Foundry makes large castings of a general nature. More than 200 workers are employed in the foundries, of whom 14 are engaged in fettling, 50 in moulding, 40 in core-making and the remainder in other work. Some 12 women are also employed in the fettling of small castings. The work done is representative of many branches of ironfounding; the building and general environment are of a kind very usual in the industry and for this reason it is felt that conclusions based on experience of these foundries can lay some claim to give a picture of the ironfounding industry as a whole.

\section{FoundRy Methods}

Ironfounding is the process of casting in iron by running molten metal into a mould of the required shape taken in sand or loam. The material forming the mould is caused to take up the appropriate shape by means of a pattern which can be regarded as a 'positive', the mould a 'negative' and the casting itself a 'positive'. There is a considerable difference in the technique of manufacture used for moulding in sand and loam so it will be convenient to consider them separately.

\section{Sand Moulding}

This method of moulding is used to make all smaller castings, and as they are often required to be produced in large numbers, mechanized systems are much in use for this type of work. A mechanized unit comprises sand preparing plant (see fig. 7), moulding machines (see figs. 1 and 8), mould conveyors and 'knock out' (see fig. 10). The patterns are made of wood, plaster or metal, and it is essential that they be made as perfect as possible because the labour employed is chiefly unskilled.

The moulds are usually made in two sections in moulding 'boxes' which, however, are not boxes in the true sense of the word as they possess sides only and have neither floor nor roof. The moulding boxes are placed on top of the pattern which is fixed on the moulding machine and are filled with sand or loam from an overhead hopper. The sand must be under rigid control and may possess either a natural bond or have added to it a synthetic bonding substance (both of which contain a proportion of alumina) the latter having an addition of coal dust to give skin finish. After the box is filled with sand it is rammed hard mechanically and then turned upside down, so that the impression of the pattern is now uppermost.

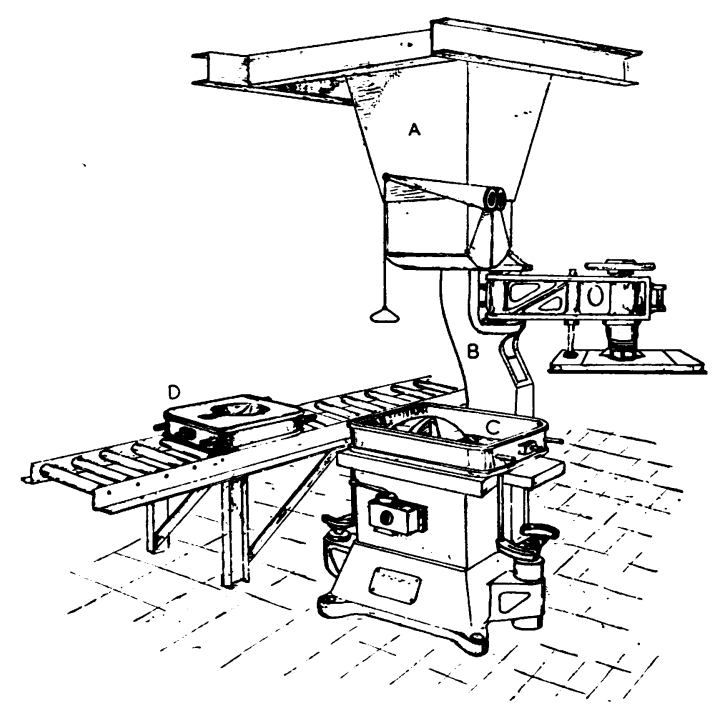

FIG. 1.-Machine moulding method.

A. Overhead hopper. B. Main column upright. C. Moulding box with pattern. D: Completed half mould.

Both sections of the mould are dealt with in this manner, but it is obvious that many internal spaces cannot be formed by a pattern directly in the sand and provision for these has to be made by means or 'cores' which are inserted after the pattern has been removed. Cores are generally made of a silica sand bonded with molasses and linseed oil, or a proprietary brand of binder which may be had in either a semi-solid or liquid state. All cores are baked in either a fixed or continuous stove which may be either coke or gas fired. 
Cores, if required, are inserted in the appropriate places and one-half moulding box is turned so that the impression of the pattern in the sand faces downwards and the two sections are then approximated. The mould is now complete and awaits the pouring of the molten metal through a special aperture left for the purpose known as the pouring basin.

The metal is melted in a cupola or forced draught furnace and when ready it is run into special ladles by which it is transported to the moulds into which it is to be poured. In addition to the pouring basin, exits known as 'risers' are sometimes added to enable the gases to escape on the introduction of the molten metal.

The moulds are now placed on the conveyor after which the metal is poured and the boxes are moved mechanically to the 'knock-out', the point at which the contents are to be removed from the box by knocking or hammering by hand. In the course of the journey, while cooling is taking place and the metal is becoming solidified, a good deal of fume is given off, chiefly due to the burning of the core oil. There is also a considerable amount of dust and fume associated with the knock-out. This takes place over a grid through which the used sand is collected on to a conveyor belt running under the floor of the shop and by which it is carried to elevators (see fig. 7). These in their turn take the sand to the mixing plant where it receives an appropriate amount of fresh sand and is then again ready for use.

After having been knocked out the casting may still retain the pouring basin and possible 'risers' and these, having served their purpose, have to be removed as well as any cores and sand which may remain adherent to it.

Excrescences of metal on the surface of the casting such as appear at the point of junction of the two halves of the moulding box have also to be dealt with and this is done by means of a pneumatic chisel or by a mechanized appliance, such as a rumbler or wheelabrator. The essential feature of both these pieces of apparatus is to cause the castings to be kept in motion while at the same time their surfaces are abraded by small shot or rather larger pieces of metal placed inside the machine for this purpose. The cleaning of the castings is completed on a grinding wheel, either fixed or movable (see fig. 12).

Hand manufacture of smaller castings follows essentially similar lines, but it is a slower process and all gradations exist from completely hand manufactured articles through a semi-mechanized system to the highly mechanized unit already described.

Sand moulding is also used for the manufacture of large castings, but the principle involved is the same, namely, pattern $>$ mould $>$ casting, although, of course, a large casting cannot be made in a 'box' but needs special construction on the foundry floor. In both sand moulding and loam moulding for the making of large castings, the moulds and cores must be dried, and blacked with a mineral blacking.

\section{Loam Moulding}

Loam, a wet and plastic sand mixture, is employed for making the moulds required for some large heavy work.

The building up of the mould starts from a castiron bottom plate upon which bricks are placed and ' bedded ' to each other with wet or putty loam in order to give the rough outline desired. When this has been done, wet loam is applied to the face and the true contour of the mould is then obtained by the use of a strickle or shaping board. The strickle board is constructed of wood in the exact shape needed and works from a spindle set up in the centre of the mould. In most cases the core is made in a similar manner (see fig. 2).

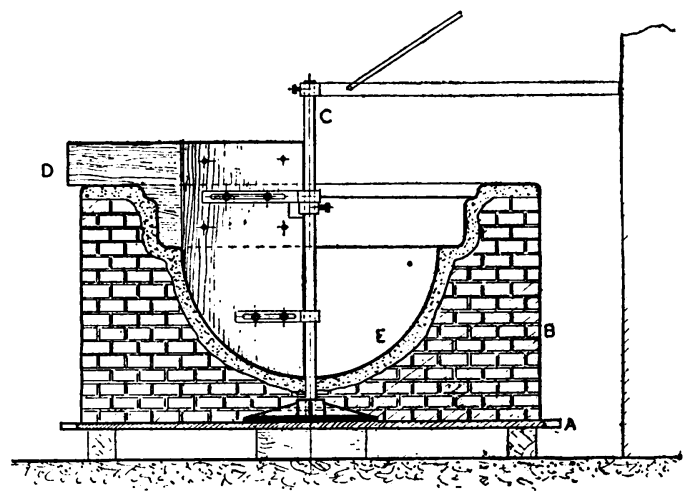

FIG. 2.-Loam moulding method.

A. Cast iron bottom plate. B. Bricks 'bedded' together with wet or putty loam. C. Centre spindle. D. Strickle or shaping board.

Pouring of the metal is carried out as has already been described under sand moulding, but the cleaning of large castings is a difficult process. They can be placed in a sand blasting chamber which is sealed off from the body of the shop and in which an operator provided with suitable protective clothing, including an air helmet, directs a current of compressed air and sand on to the casting. This method is not practicable in all cases, as for example the very large casting, and until recently it has only been possible to carry out the fettling in these cases by hand or with the help of pneumatic chisels and swing frame grinders.

A new method known as hydro-blasting has, however, been devised in the United States of America, by means of which a high velocity jet of sand and water is projected on to the castings, thereby removing moulding material, cores and scale (see fig. 13). In addition the method keeps the atmosphere free from dust. If these claims are substantiated, this method may be one important solution of the dust problems in this industry.

\section{Environmental Studies}

Heating and General Ventilation

Table 1 shows the results of the readings taken with the kata thermometer (dry bulb) as well as 
recordings of the whirling psychrometer. These findings show the ventilation to be adequate and the cooling power satisfactory for the type of work being done so far as it is possible to assess. For a shop in which it is obviously difficult to regulate the heat, from the nature of the work, these figures cannot be regarded as unsatisfactory.

TABLE 1

SURVEY OF THE EFFICIENCY OF FOUNDRY HEATING AND VENTILATION

\begin{tabular}{|c|c|c|c|c|c|c|c|}
\hline \multirow[t]{2}{*}{ Position } & \multirow[t]{2}{*}{$\begin{array}{l}\text { Date of } \\
\text { reading }\end{array}$} & \multirow[t]{2}{*}{$\begin{array}{l}\text { Hour of } \\
\text { reading }\end{array}$} & \multicolumn{2}{|c|}{$\begin{array}{c}\text { Tempera- } \\
\text { ture assessed } \\
\text { by whirling } \\
\text { psychro- } \\
\text { meter }\end{array}$} & \multicolumn{2}{|c|}{$\begin{array}{c}\text { Cooling } \\
\text { power } \\
\text { by kata } \\
\text { thermo- } \\
\text { meter } \\
\text { Dry bulb }\end{array}$} & \multirow{2}{*}{$\begin{array}{c}\text { Air } \\
\text { velocity } \\
\text { (feet } \\
\text { per } \\
\text { minute) }\end{array}$} \\
\hline & & & $\begin{array}{l}\text { Wet } \\
\text { bulb }\end{array}$ & $\begin{array}{l}\text { Dry } \\
\text { bulb }\end{array}$ & $\begin{array}{l}\text { Head } \\
\text { level }\end{array}$ & $\begin{array}{c}\text { Floor } \\
\text { level }\end{array}$ & \\
\hline $\begin{array}{l}\text { Foundry No. } 2 \\
\text { Blackstone Bed } \\
\text { Foundry No. } 1 \\
\text { Core shop . . } \\
\text { Core shop } \\
\text { Foundry No. i } \\
\text { New fettling } \\
\text { shop ... }\end{array}$ & $\begin{array}{l}26.2 .43 \\
26 \cdot 2 \cdot 43 \\
26 \cdot 2 \cdot 43 \\
26 \cdot 2 \cdot 43 \\
18 \cdot 1 \cdot 45 \\
18 \cdot 1 \cdot 45\end{array}$ & $\begin{array}{l}10 \cdot 15 \\
10 \cdot 30 \\
10 \cdot 50 \\
11 \cdot 15 \\
14 \cdot 30 \\
14 \cdot 45 \\
15 \cdot 00\end{array}$ & $\begin{array}{l}53 \\
53 \\
53 \\
52 \\
50 \\
47 \\
47\end{array}$ & $\begin{array}{l}55 \\
58 \\
62 \\
58 \\
52 \\
52 \\
50\end{array}$ & $\begin{array}{c}11 \cdot 0 \\
8.0 \\
8.5 \\
10.0 \\
12 \cdot 75 \\
16.0\end{array}$ & $\begin{array}{r}9 \cdot 5 \\
8 \cdot 0 \\
\frac{8}{8 \cdot 0} \\
10 \cdot 0 \\
14 \cdot 0 \\
11 \cdot 0\end{array}$ & $\begin{array}{r}100 \\
40 \\
65 \\
90 \\
120 \\
220\end{array}$ \\
\hline
\end{tabular}

\section{Fumes}

The fumes in the foundry are derived chiefly from the burning of bonding substances used in the core sand such as linseed oil, dextrine, resins or tar oils. Those given off by the resins are not unpleasant although the fumes derived from linseed oil are rather acrid; in general, however, they appear to be innocuous, except those produced from tar oils, which may possibly be carcinogenic.

\section{Dust Hazard}

It has long been known that certain foundry workers are subjected to abnormal dust hazards and many investigations have been carried out in the past, notably in Australia and America. Only a very limited investigation of the dust environment was possible in this survey, the work being restricted by time and availability of apparatus. The results, however, may form a useful introduction to a more comprehensive study, and the experience gained be of some value to subsequent workers in the subject.

In order that an estimate may be made of the potential danger of dust inhaled during any industrial operation, precise knowledge is required of the following four factors:

(1) The average concentration of the dust in the air breathed by the worker during the operation.

(2) The approximate time which the worker spends in this environment.

(3) The chemical composition of the inhaled dust.

(4) The size frequencies of the dust particles inhaled.

\section{Technique}

(a) Collection of Samples.-In making any decision as to the method to be adopted to give this information, the investigator must consider the various methods which he may have available, and assess each from a practical standpoint. Two factors must be emphasized. It is well known that the dust concentrations of a dusty occupation vary enormously so that 'spot' samples are of very limited utility. Secondly, it is known that the technique adopted will affect the magnitude of the estimates. Thus, results obtained with the Owens jet dust counter will generally be considerably less than those obtained with the Midget Impinger. Generally, the correlation between any two methods is very poor indeed. It is necessary, therefore, in presenting the results of an investigation that the technique employed should be rigidly defined.

In order that an average sample may be obtained over a lengthy period, and be subsequently submitted to analysis, two general methods are available, the Impinger and filtration. American practice has long favoured the former. Two criticisms may be advanced against the Impinger: transport and transfer of a liquid medium is inconvenient in a works; and secondly, the high speed at which the particles impinge on the base of the tube may fracture the larger particles, thus giving an erroneously high number when the particles are counted. The Briscoe crystal filter overcomes these difficulties.

The dust enters the filter at a low speed and may be recovered easily from the crystal bed and prepared for particle counts or analysis. The microscope slide may be prepared of a correct density to facilitate counting, a difficult procedure when using the Konimeter or similar spot methods. Although concentrations may amount to millions of particles per cubic foot, the actual weight of dust in suspension is so small that a micro balance is practically essential for the determination of mass concentration and chemical analysis.

Unfortunately we were unable to obtain such a balance in the time available, and the ordinary analytical balance was of a type unsuitable for adaptation to micro weighing. All weighings are limited to an accuracy of $0.2 \mathrm{mg}$., this being determined over a series of repeated investigations using a carefully controlled technique. So that maximum quantities of dust should be available for analysis, samples Nos. 1-7 were taken with a rotary hand pump attached to a large Briscoe filter. Five subsequent samples were taken with hand syringe (capacity $0.0055 \mathrm{cu}$. $\mathrm{ft}$.) coupled to a simple microcrystal filter, a number of which may be carried about ready loaded in a small box. A tubular extension was fitted to the filter, and the pump operated at a speed sufficient to draw in falling particles smaller than 35 microns.

(b) Chemical Analysis.-In view of the small amounts of dust available for analysis only a very limited empirical procedure is practicable. A portion of the collected dust was placed in a small platinum crucible made from foil and subjected to three processes in the crucible. (1) Ignition at $700^{\circ} \mathrm{C}$. to determine the percentage of combustible matter. (2) Extraction with dilute hydrochloric acid to give the percentage of soluble material (mainly iron). (3) Evaporation with hydrofluoric acid and subsequent ignition to constant weight to remove the total silica. The greater part of the total silica would, in fact, be free silica in the samples examined. The residues of all samples were then bulked and the percentage of alumina determined after fusion with sodium carbonate.

Obviously the accuracy is dependent on the number of operations involved and the weight of the available samples. Without a micro balance the accuracy obtainable is low and since the analysis refers to all particles this may not be the same for all size frequencies.

(c) Microscopic Methods.-The method adopted for the determination of the number of particles and the size frequency of the dust has been described in some detail by Lowrie Fairs (1944). The portion of the collected dust not used in chemical analysis was agitated in alcohol. The dispersed suspension was then further agitated by means of air blown from a pipette. A drop on the end of the pipette was then transferred to a 
haemocytometer cell and after allowing the sample to dry, the dust particles were counted and sized by means of a Patterson graticule in the eye-piece of the microscope. Having established the relative frequency of occurrence of each size of particle, a weighted average may be calculated assuming that the particles weigh the same as a cube of the same dimensions, the specific gravity being an average calculated for the dust. This has been shown to be approximately true. The number of particles present in the original sample in each size range may then be calculated. The method has two disadvantages. It is by no means an easy task to prepare an even deposit on a slide truly representative of the original dust. The total weight of the dust on the slide will only be a fraction of a milligramme. Again, only a small fraction of this deposit will be sized against the graticule. Secondly, the greatest weight of the dust will be in the large particles which are numerically insignificant. One particle 70 microns in diameter is equivalent in weight to 343,000 particles of one micron. Great care must be exercised in order that the proportion of large particles may be estimated correctly. Between 2000 and 3000 particles were sized for each sample. The process is, therefore, a laborious procedure. Furthermore, the microscope itself has limitations.

The microscope available was a Watson 'Edinburgh Student' fitted with mechanical stage and substage condenser (NA 1-0). A 16-mm. objective combined with a $\times 7$ Holos eye-piece incorporating a Patterson graticule, was used for measuring particles in the range 10-70 microns. Particles below 10 microns in size were measured with a 4-mm. apochromatic objective. A blue light filter was incorporated to facilitate the observation of the smallest particles. The resolving power of a microscope depends largely on the wavelength of the light source and the numerical aperture of the objective and substage condenser. Particles much below 0.5 microns in size cannot be discriminated with the apparatus. Since the numerical proportion of particles below 1.5 microns in size is very large it is apparent that microscope counts are subject to large variations according to the apparatus available and possibly also to the observer, since particles near the visible limit are exceedingly difficult to define. In spite of the limitations outlined above, and the development of other micro methods for the determination of size frequency and total surface area, the microscope is still the most positive method available and probably the most satisfactory.

\section{Location of Samples}

All samples were taken from a position near to the operative's mouth unless otherwise stated. Generally the filter was inverted and the air intake speed adjusted so that only particles less than 40 microns in size would be included in the sample. In actual practice particles much larger than this are projected at high speed by certain processes and are retained by the filter. In the case of two samples (Nos. 1 and 7) the proportion was so excessive that particles in excess of 70 microns were removed by sieving the dust samples on a microsieve. If more than one operator was engaged on similar work the sample was divided between the various workers. Samples generally took about one hour to collect.

Sample No. 1. Medium Fettlings. The site was in the old Fettling Shop for the treatment of castings up to about $3 \mathrm{cwt}$. Over a period of more than one hour three fettlers were sampled. The fettlers used compressed-air picks. It was noticed that the worst atmospheric conditions were prevalent when cleaning off the dust by the process of 'blowing off' with the nozzle. In addition, dust was blown into the operator's face by the exhaust when cleaning the inside of castings. The actual fettling may occupy one-third to one-half of the worker's time. A fair current of air was moving across the shop.

Sample No. 2. The general body of No. 1 Foundry. In order to collect a maximum amount of dust for analysis the filter was placed facing upwards for this sample. No machinery was nearer than $12 \mathrm{ft}$. The location was away from, but surrounded by a variety of foundry processes. These included medium and fine fettling, pneumatic and spray-type mould fillings, shaking out of moulds, wheelabrating, metal pouring and rumbling. Sampling was continued for 35 minutes.

Sample No. 3. Mould Filling. This sample was taken at the breathing level of two mould fillers during the actual operation of the pneumatic filling. Dusting, brushing and blowing off processes were not included in the sample although residual pollution from these sources may still have persisted. This sample, therefore, only refers to the actual filling of the mould and tamping off. The moulds were of moderate size and took from 10 to 14 seconds to fill. Not more than one-seventh of the worker's time was spent on this operation.

Sample No. 4. The 'Knock out'. This sample was taken during the emptying of the moulds after partial cooling. The moulding material was emptied over a grating. Fumes were excessive, but this did not appear to be a particularly dusty occupation. One operator possibly spent one-third to one-half of the working shift actually knocking out the moulds.

Sample No. 5. Defective Wheelabrator. The airborne dust was sampled about four feet from the wheelabrator. A considerable dust cloud was carried towards No. 1 Foundry during operation. This machine is working for about one-third of the shift and although workers were not in the immediate vicinity, dust was carried towards No. 1 Foundry and in the path of several workers. The machine is due for immediate replacement.

Sample No. 6. Small Fettlings. The small fettlings are carried out in a shop adjoining No. 1 Foundry. It is a new shop and is cleaned regularly. The conditions compare very favourably with the rest of the foundry as regards house-keeping. One-half of the sample was taken from the breathing level of an operator working a Spenser Duplex high-speed grinder. This operator was the only one observed to be wearing a mask. The shop is used exclusively for grinding off excess metal from light castings. The second half of the sample was obtained during the operation of a small pneumatic carborundum high-speed grinder. There were several of these machines in operation and none were fitted with dedusting devices. The compressed air exhaust did not appear to aggravate the dust nuisance and conditions appeared relatively clear in the shop. Probably operators are grinding about three-quarters of the shift.

Sample No. 7. Large Fettling. This work was carried out near the closed end of one shop. Castings were very large (up to 10 tons) and fettling occupies probably two-thirds of the shift. The sample covered two fettlers cleaning three large castings. Much dust was observed to be dispersed into the air during the blow-off period. Air conditions were comparatively static in this part of the foundry.

Sample No. 8. Core Shop. This shop is an annexe to No. 1 Foundry, and as with Sample No. 6 conditions are no doubt improved by this arrangement. The mixture, which is hand filled by girls, consists of sea sand, 'Cordex' (an artificial bonding substance), and linseed oil. Sixteen workers were employed and the work was practically continuous. All these workers contributed to the sample.

Sample No. 9. General Body, No. 1 Foundry. The sample was taken in about the middle of No. 1 Foundry. Immediately opposite was a large opening into No. 2 Foundry. A 'Slinger', working about 20 per cent. of the sampling time, was situated $10 \mathrm{ft}$. away. 
Sample No. 10. General Body, No. 1 Foundry. The sampling position was $37 \mathrm{yd}$. from the top end of No. 1 Foundry, and was situated in the space between two large moulds which were in the process of being filled. Large moulds were being constructed nearby.

Sample No. 11. General Body, No. 2 Foundry. Sampling position was 37 yards from the top end of the foundry. A large mould was being filled close by the position and this part of the foundry was very busy with various operations in the vicinity.

Sample No. 12. General Body, No. 2 Foundry. The sample was taken in the centre of the foundry immediately opposite a large annealing oven.

\section{Discussion of Results}

The mass concentration of each sample is given in Table 2 and the chemical analysis in Table 3.

TABLE 2

\section{MASS CONCENTRATION OF AIRBORNE DUST AT BREATHING HEIGHT}

\begin{tabular}{|c|c|c|c|c|c|}
\hline $\begin{array}{c}\text { Sample } \\
\text { No. }\end{array}$ & $\begin{array}{l}\text { Location or } \\
\text { occupation }\end{array}$ & $\begin{array}{c}\text { Wt. of } \\
\text { dust } \\
\text { (mg.) }\end{array}$ & $\begin{array}{l}\text { Vol. air } \\
\text { sampled } \\
\text { (cu.ft.) }\end{array}$ & $\begin{array}{l}\text { Mg. } \\
\text { per } \\
\text { cu. ft. }\end{array}$ & $\begin{array}{l}\text { Mg. } \\
\text { per cu. } \\
\text { metre }\end{array}$ \\
\hline $1 *$ & $\begin{array}{l}\text { Medium-sized } \\
\text { fettlings }\end{array}$ & $71 \cdot 7$ & $20 \cdot 74$ & $3 \cdot 46$ & $122 \cdot 1$ \\
\hline 2 & $\begin{array}{l}\text { Main Body, } \\
\text { No. } 1 \text { Foundry }\end{array}$ & $19 \cdot 2$ & $16 \cdot 00$ & $1 \cdot 20$ & $42 \cdot 4$ \\
\hline 3 & $\begin{array}{l}\text { Pneumatic } \\
\text { mould filling }\end{array}$ & $23 \cdot 6$ & $11 \cdot 20$ & $2 \cdot 11$ & $74 \cdot 5$ \\
\hline $\begin{array}{l}4 \\
5\end{array}$ & $\begin{array}{l}\text { Shaking-out } \\
\text { Defective }\end{array}$ & $15 \cdot 6$ & 13 & $1 \cdot 16$ & $40 \cdot 9$ \\
\hline $\begin{array}{l}6 \\
7^{*} \\
8 \dagger \\
9 \dagger\end{array}$ & $\begin{array}{l}\text { wheelabrator } \\
\text { Small fettling .. } \\
\text { Large fettling .. } \\
\text { Core shop .. } \\
\text { Main Body, }\end{array}$ & $\begin{array}{r}31 \cdot 6 \\
14 \cdot 3 \\
48 \cdot 2 \\
1 \cdot 3\end{array}$ & $\begin{array}{r}9 \cdot 18 \\
15 \cdot 39 \\
10 \cdot 00 \\
5 \cdot 55\end{array}$ & $\begin{array}{l}3 \cdot 44 \\
0 \cdot 93 \\
4 \cdot 82 \\
0 \cdot 23\end{array}$ & $\begin{array}{r}121 \cdot 4 \\
32 \cdot 8 \\
170 \cdot 0 \\
8 \cdot 2\end{array}$ \\
\hline $10+$ & No. 1 Foundry & $1 \cdot 7$ & $5 \cdot 55$ & 0.31 & $10 \cdot 8$ \\
\hline $10 T$ & No. 1 Foundry & $2 \cdot 9$ & $5 \cdot 55$ & 0.52 & $18 \cdot 4$ \\
\hline $11 \dagger$ & $\begin{array}{l}\text { Main Body, } \\
\text { No. } 2 \text { Foundry }\end{array}$ & $2 \cdot 2$ & $5 \cdot 55$ & 0.40 & $14 \cdot 0$ \\
\hline $12 \dagger$ & $\begin{array}{l}\text { Main Body, } \\
\text { No. } 2 \text { Foundry }\end{array}$ & $2 \cdot 2$ & $5 \cdot 55$ & 0.40 & $14 \cdot 0$ \\
\hline
\end{tabular}

TABLE 3

CHEMICAL ANALYSIS OF AIRBORNE DUST

\begin{tabular}{|c|c|c|c|c|}
\hline Sample No. & 1 & 7 & $3+4$ & 2 \\
\hline \multirow{6}{*}{$\begin{array}{l}\text { Wt. of sample analysed } \\
\text { (mg.) . } \\
\text { Per cent. loss on ignition } \\
\text { (combustible matter) . } \\
\text { Per cent. soluble in hydro- } \\
\text { chloric acid (mainly } \\
\text { iron, etc.) } \\
\text { Per cent. total silica (loss } \\
\text { with hydrofluoric acid) } \\
\text { Per cent. residue . } \\
\text { Per cent. alumina }\left(\mathrm{Al}_{2} \mathrm{O}_{3}\right) \\
\text { in residue }\end{array}$} & $52 \cdot 8$ & $29 \cdot 8$ & $14 \cdot 0$ & $8 \cdot 8$ \\
\hline & $10 \cdot 0$ & 8.0 & 21.0 & $41 \cdot 0$ \\
\hline & $11 \cdot 0$ & $18 \cdot 0$ & $11 \cdot 0$ & $18 \cdot 0$ \\
\hline & $67 \cdot 0$ & 68.0 & $50 \cdot 0$ & $20 \cdot 0$ \\
\hline & $12 \cdot 0$ & 6.0 & 18.0 & 21.0 \\
\hline & \\
\hline
\end{tabular}

The weight distribution and the number of particles per cubic foot for a limited range of size frequencies

* From samples 1 and 7 dust over 70 microns in size was removed by a micro-size sieve. Including this oversize dust the concentrations were 5.77 and $5.22 \mathrm{mg}$. per cu. ft. respectively.

t Samples taken with micro filter and hand syringe.
TABLE 4

WEIGHT DISTRIBUTION AND PARTICLES PER CUBIC FOOT

1. Number of PARTiCles Per Cubic foot Sample No.

\begin{tabular}{|c|c|c|c|c|c|c|}
\hline & $\begin{array}{c}1 \\
\text { Medium } \\
\text { fettling }\end{array}$ & $\left|\begin{array}{c}2 \\
\text { General } \\
\text { body }\end{array}\right|$ & $\begin{array}{l}3 \\
\text { Pneu- } \\
\text { matic } \\
\text { filling }\end{array}$ & $\begin{array}{c}4 \\
\text { Shake } \\
\text { out }\end{array}$ & $\left|\begin{array}{c}6 \\
\text { Small } \\
\text { fettling }\end{array}\right|$ & $\begin{array}{c}7 \\
\text { Large } \\
\text { fettling }\end{array}$ \\
\hline Sp. gr. (calc.) & $2 \cdot 65$ & $2 \cdot 4$ & $2 \cdot 4$ & $2 \cdot 4$ & $4 \cdot 0$ & $2 \cdot 65$ \\
\hline 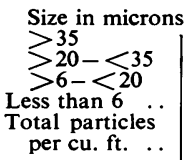 & $\begin{array}{l}0.005 \\
0.011 \\
0.095 \\
4.84 \\
4.95\end{array}$ & $\begin{array}{l}\text { (Num } \\
0.002 \\
0.006 \\
0.054 \\
1.81\end{array}$ & $\begin{array}{c}\text { ber of pa } \\
0.004 \\
0.01 \\
0 \cdot 108 \\
3 \cdot 55 \\
3.67\end{array}$ & $\begin{array}{r}\text { articles } \\
0.002 \\
0.006 \\
0.071 \\
2.625\end{array}$ & \begin{tabular}{|}
$\left.\times 10^{6}\right)$ \\
0.001 \\
0.003 \\
0.037 \\
2.27 \\
2.31
\end{tabular} & $\begin{array}{l}0.004 \\
0 \cdot 031 \\
0 \cdot 607 \\
27 \cdot 57 \\
\\
28 \cdot 20\end{array}$ \\
\hline $\begin{array}{l}\text { Total particles } \\
\text { per c.c. }\end{array}$ & $175 \cdot 000$ & $66 \cdot 000$ & $129 \cdot 000$ & 95.000 & 81.000 & 995.000 \\
\hline
\end{tabular}

\begin{tabular}{|c|c|c|c|c|c|c|}
\hline $\begin{array}{l}>35 \\
>20-<35 \\
>6-<20\end{array}$ & $\begin{array}{c}73 \cdot 3^{2} \\
16 \cdot 4 \\
7 \cdot 6 \\
2 \cdot 7\end{array}$ & $\begin{array}{l}\text { WEIGHT } \\
\begin{array}{|r|}61.8 \\
23.8 \\
12.0 \\
2.4\end{array}\end{array}$ & $\begin{array}{l}\text { PER CE } \\
\begin{array}{|r|r}60 \cdot 0 \\
23 \cdot 5 \\
13 \cdot 3 \\
3 \cdot 2\end{array}\end{array}$ & $\begin{array}{r}59 \cdot 1 \\
22 \cdot 9 \\
13 \cdot 3 \\
4 \cdot 7\end{array}$ & $\begin{array}{r}51 \cdot 9 \\
27 \cdot 5 \\
15 \cdot 8 \\
4.8\end{array}$ & $\begin{array}{l}28 \cdot 9 \\
31 \cdot 3 \\
27 \cdot 6 \\
12 \cdot 2\end{array}$ \\
\hline
\end{tabular}

is shown in Table 4. The percentage weight undersize for each particle size is graphed in fig. 3 and $3 a$, on a log-log scale. In order to show the relationship between mass concentration and particle

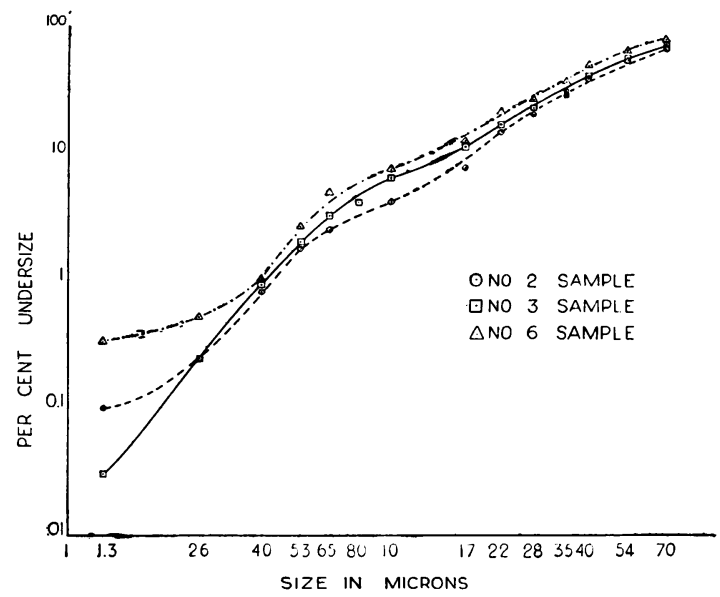

SIZE FREOUENCY CURVES OF AIRBORNE FOUNDRY DUSTS FIG. 3.

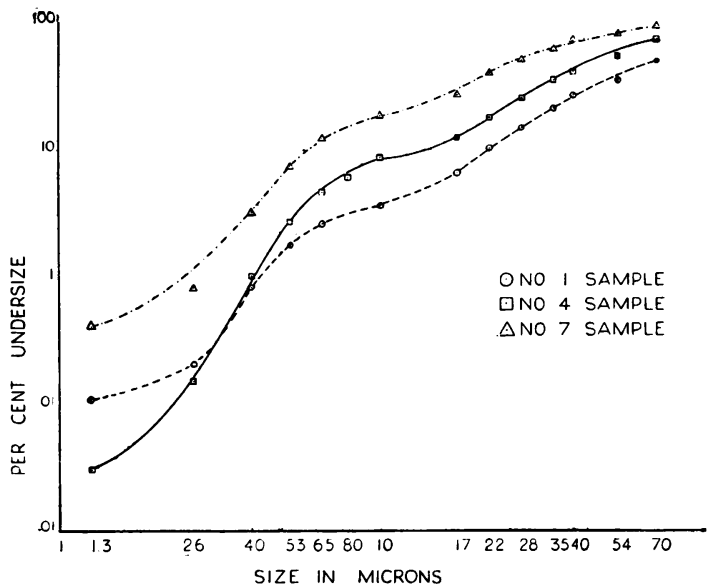

SIZE FREQUENCY CURVES OF AIRBORNE FOUNDRY DUSTS

FIG. 3A. 
number per cubic foot a diagram has been prepared (fig. 4 and $4 a$ ) showing the effect of exclusion of large particles on the mass concentration and particle count. The mass concentration shows at

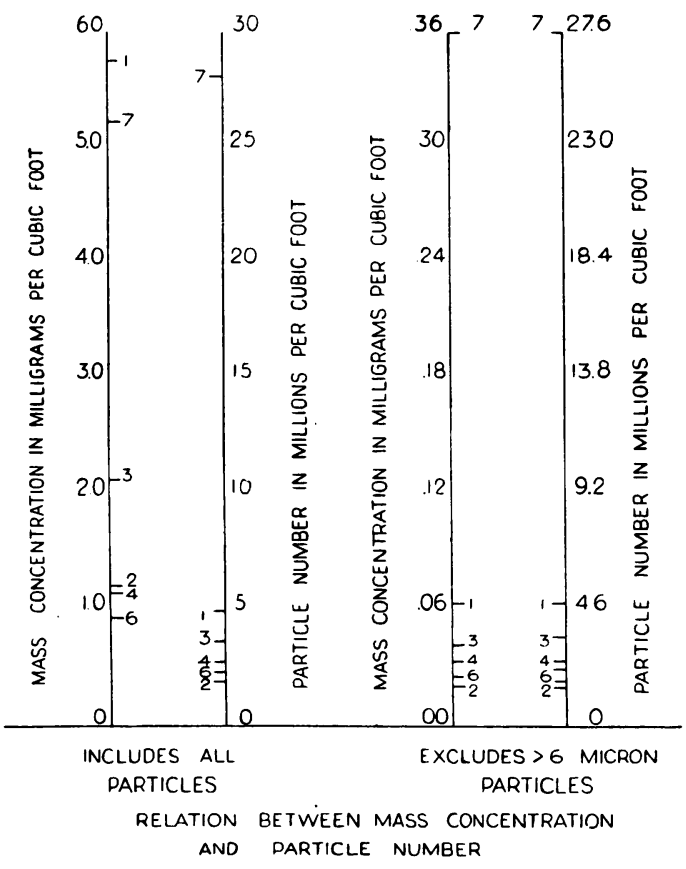

FIGS. 4 and 4A.

once that the medium and large fettlers have the dustiest occupation. The defective wheelabrator is a large source of pollution, but this pollution does not appear to have affected conditions materially in the general body of the foundry. The vast majority of workers spend most of their time in the conditions revealed by samples taken from the general body of the foundry. These show a rather striking constancy when due allowance is made for sample No. 2 which included particles of all sizes. Conditions appear to be better in small shops such as the small fettling and core shop. Cleaner housekeeping is possible in these circumstances and the effect is reflected in lower dust concentrations. The situation of these shops in annexes off the main foundry mitigates the effect of pollution from this source.

Chemical analysis shows that the dust from medium and large fettling consists largely of silica particles. This was confirmed by the microscope. Although it is impossible to identify very small particles it is reasonable to assume that these particles are similar in chemical composition to the large particles. The pollution in the general body of the foundry is definitely higher in combustible matter and lower in silica content.

The character of the airborne dust produced during the filling of moulds and the shake out is intermediate between the extremes of large fettling and general body, but since the mass concentrations are much lower and the time spent by the operator in these occupations is much less the silica hazard is much lower than that of the fettler.

Microscopic examination of the dusts shows that numerically $96-98$ per cent. of the particles are less than 6 microns in size. The actual weight of this fraction may be less than 3 per cent. of the total weight of dust. Since the dust which may be retained by the lung tissue is above the resolving limit of the microscope and below 6 microns in size, it follows that mass concentrations without numerical counts cannot provide a true measure of the dust hazard unless special precautions are taken to exclude particles in excess of the upper size limit. This is strikingly illustrated by a comparison of samples Nos. 1 and 7 (fig. 4 and 4a). Including all particles, sample No. 1 gave a slightly higher concentration than sample No. 7. The particle count, however, showed that the hazard for the large fettler (No. 7, 995 particles per c.c.) was more than five times that of the medium fettler (No. 1, 175 particles per c.c.). The airborne dust from the latter source is much coarser than that produced from the former (fig. $3 a$ ). This may be due to the nature of the process although it seems likely that air conditions may be partly responsible. The medium fettler is often working on the inside of castings, and in this instance there was a definite ventilation current across the shop. Large particles projected from a process at high velocity are only partly deflected by air currents whereas small particles will tend to be carried away from the worker. If due allowance is made for the higher silica content of the air breathed by the large fettler, then the silica hazard of this worker is fifty times that of a worker in the general body of the foundry. Medium fettling represents a nine times greater hazard, and pneumatic mould filling and shaking out no more than five times. Owing to the relatively short time actually spent by the worker on these processes the dust hazard will be much less than is indicated above. Large particles of coal dust were prevalent in the air of the main body (sample No. 2) and in the samples from pneumatic filling and the shake out (Nos. 3 and 4). This last included many particles which were partly coked, and in view of the excessive fumes breathed by the worker the harmful effects of tar cannot be ignored. The sample from the small fettling shop consisted largely of iron and carborundum particles, and the concentration would not appear to be excessive. Although the workers in the core shop are handling a sand mixture most of their time, the nature of the mixture with the linseed oil binding is such that air pollution from this source is very low indeed (sample No. 8). Micro samples from the main body of the foundries (Nos. 9, 10, 11 and 12) show that there is no excessive pollution in the foundry atmosphere judged by internal standards.

In the routine control of atmospheric pollution such as that which exists in the foundry, measurement of mass concentrations represents the simplest way of keeping a check on changing conditions. 
Fig. 4 and $4 a$ show very clearly that if the large particles could be excluded, then the mass concentration would also enable the dust hazard to be measured accurately. This presents some difficulty for samples which are made up partly of highvelocity particles. The terminal velocities of quartz particles falling in still air are given in Table 5. By adjusting the air intake speed to the filter, and fitting a long tubular extension to it, the exclusion of the larger particles does not appear to be impracticable. The intake tube would need to be fitted with a'smoothing device and to have a rightangle bend in order to stop high-speed particles. If the air intake speed were adjusted to exclude particles greater than 10 microns, then the concentration would be a fair measure of the dust hazard. Whilst the cut-off of particles larger than 10 microns in size should be reasonably sharp, only a fraction of those just below this size limit would be included in the sample. The proportion would increase rapidly as the motion of the particles became more dependent on the movement of the air current in the low size-frequency ranges. With this method a micro balance sensitive to $0.01 \mathrm{mg}$. would be essential.

TABLE 5

\section{FREE FALLING SPEED OF QUARTZ} PARTICLES IN AIR

$\begin{array}{cc}\begin{array}{c}\text { Particle diameter } \\ \text { (in microns) }\end{array} & \begin{array}{c}\text { Approximate terminal } \\ \text { velocity (cm. per sec.) }\end{array} \\ 100 \cdot 0 & 41 \cdot 0 \\ 75 \cdot 0 & 30 \cdot 0 \\ 50 \cdot 0 & 12 \cdot 5 \\ 30 \cdot 0 & 4 \cdot 5 \\ 10 \cdot 0 & 0.5 \\ 5 \cdot 0 & 0 \cdot 1 \\ 2 \cdot 5 & 0.03\end{array}$

As an alternative to this procedure, the microscope can give a good estimate of the total number of particles below 6 microns in size, providing a sizefrequency curve is not required. In this case the inclusion or exclusion of large particles from the sample is immaterial. Having obtained a satisfactory average sample by means of the crystal filter and hand syringe, the crystals may be separated from the dust by means of a hand centrifuge. The dust may then be agitated in a definite volume of alcohol. After agitation a suitable quantity of the suspension is quickly removed by means of a micro pipette and transferred to a moist chamber microscope slide. When the slide has dried and a suitable deposit of sufficient density obtained, counts may be made at random parts of the deposit by means of the 4-mm. objective only, with a Patterson graticule in the eye-piece, ignoring the particles above 6 microns in size. Having established an average count within the rectangle of the graticule, simple calculation will give the total particle count on the slide and so the total particles in the original suspension. Much of the trouble in preparing a slide from a suspension is in obtaining a representative sample of the large particles. Since these are numerically insignificant, and of little interest from the point of view of the health of the worker, the sampling difficulties and the necessity to undertake a great many size comparisons would largely disappear with this technique. The actual count and calculation would not take more than an hour and since the moist chamber will hold a relatively large volume of liquid $(0.3$ c.c. $)$ the error from this is much less than that incurred by using the standard haemocytometer cell. 'After filling the cell, the chamber should be allowed to stand at room temperature when an even deposit of the dust in suspension will be deposited on the slide.

\section{Health Studies}

Although some indication of diseases to which the foundry worker is subject can be obtained from a study of the Occupational Mortality figures of the Registrar-General's Decennial Supplement (1931) the figures are apt to be misleading for a variety of reasons. It has therefore been found advisable to restrict this part of the investigation to known facts within our own experience, namely, the incidence of sickness and accidents among foundry workers compared with a similar number of workers in another department.

\section{Sickness and Accidents}

The reaction of the foundry man to his environment has been attempted by comparing the nature of the absence due to sickness and accidents occurring in the Foundries with that taking place in the Constructional Department at Butterley during the past twelve months. The Constructional Department has been selected for comparison not only because there is not an undue disparity between the numbers employed in it and the foundry respectively, but also because the Registrar-General's Decennial Supplement (1931) showed no significant rise in mortality among constructional engineers due to conditions other than accident, unless a possible significant excess of cancer deaths is taken into account.

The results of these studies are shown in Fig. 5 and Table 6 , and it will be seen that contrary to what might have been expected, the number of cases of respiratory disease occurring in the Foundries was lower than in the Constructional Department, although the average number of days lost per case was higher. Affections of the skin showed a greater incidence though rheumatic cases were in about the same proportion, but accidents were fewer and less time was lost from this cause, despite the fact that two cases of herniotomy are included in the accident figures.

\section{Respiratory Disease}

The fact that the average number of days lost per case due to respiratory disease is more in the Foundries than in the Constructional Department suggested that the nature of the respiratory conditions might be of a more serious nature among 
TABLE 6

CASES OF SICKNESS AND ACCIDENT ABSENCE IN THE FOUNDRIES AND CONSTRUCTIONAL DEPARTMENT AT BUTTERLEY

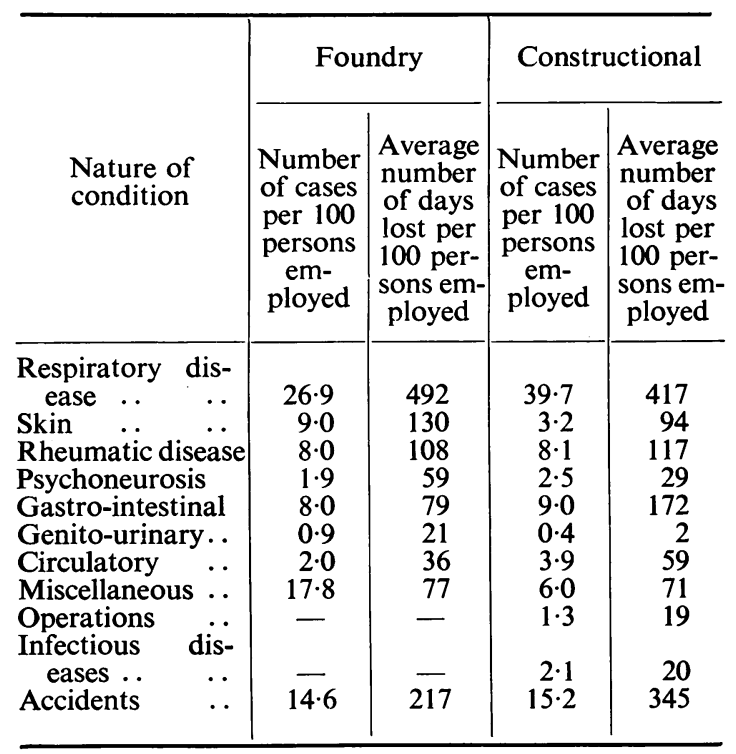

Foundries (219 workers), Constructional (282 workers).

workers in the foundries, due possibly to the dusty atmosphere, so an investigation was carried out to determine the extent to which dust had affected the lungs. Sixty men working in the Foundries were examined and a full history, including a complete occupational history was taken from each person; this was followed by a physical examination including chest radiography, and the results of this investigation are shown in Table 7. Table 8 gives in summary form the results of the x-ray survey in the different age groups of those examined, while

Foundry

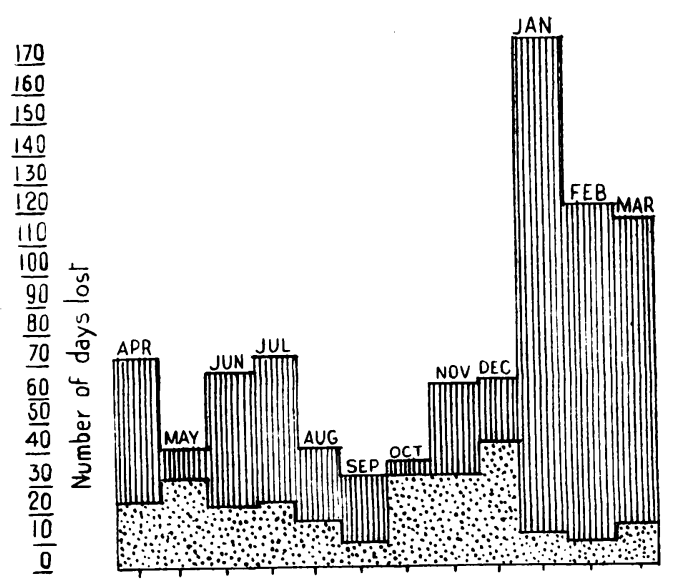

APR MAY JUN JUL AUG SEP OCT NOV DEC JAN FEB MAR

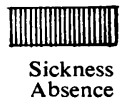

in Table 9 is given the length of time to which those examined were exposed to a dust risk. No cases of tuberculosis or silicosis were noted.

Butterley is in a coal-mining district and the investigation was complicated by the fact that the occupational history of a number of those examined included coal mining, itself a dusty occupation. Neither of the fettlers showing lung changes, however, had been at any time engaged in colliery work, although two out of the eight moulders had been coal miners and two out of the three noted amongst the other occupations.

This investigation indicates, therefore, that $21 \mathrm{per}$ cent. of all the foundry workers examined showed some evidence of dust changes in the lungs, but 40 per cent. of fettlers were affected in comparison with 25 per cent. of moulders and 12 per cent. of other workers: moreover the degree of dustiness in the fettlers' lungs was much heavier than in the case of other workers in the foundry.

In general the degree of dustiness of the lung depends on the length of exposure to the dusty environment and, although there is some idiosyncrasy, exposure of many years duration is usually necessary before any marked changes occur. Thus, in the case of the fettlers, those showing evidence of dust in the lungs had been exposed to risk for over twenty years.

Although the total number of those examined is small, the results are largely in accordance with the findings in other and more extensive surveys of a similar nature (Sander, 1938; McConnell \& Fehnel, 1934) indicating that there is a greater risk of the occurrence of dust changes in the fettler than in other workers in the foundry. That dust changes should occur more commonly in the lungs of the fettler is not surprising in view of the mass concentration of the dust, the size of particles, and the 


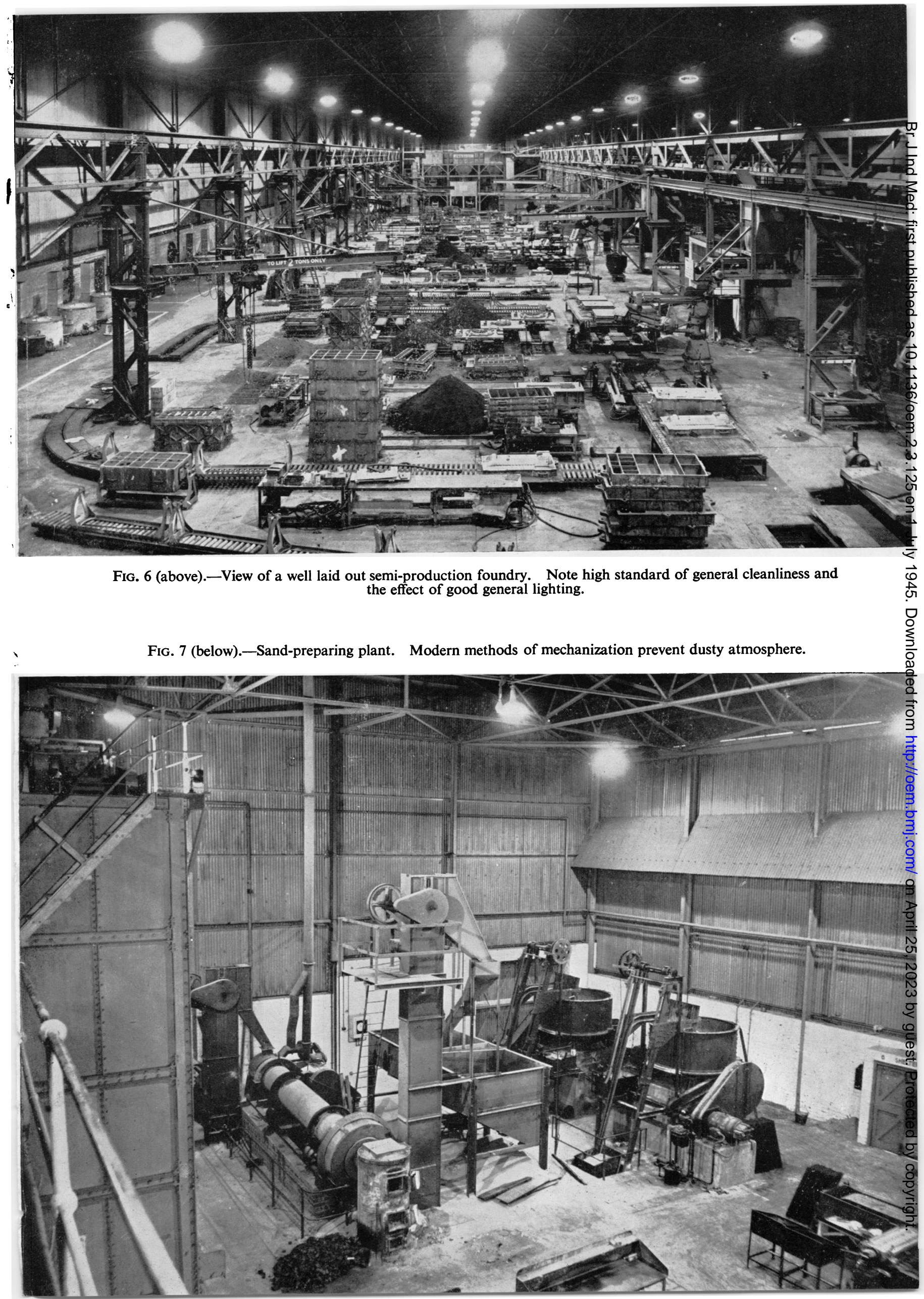




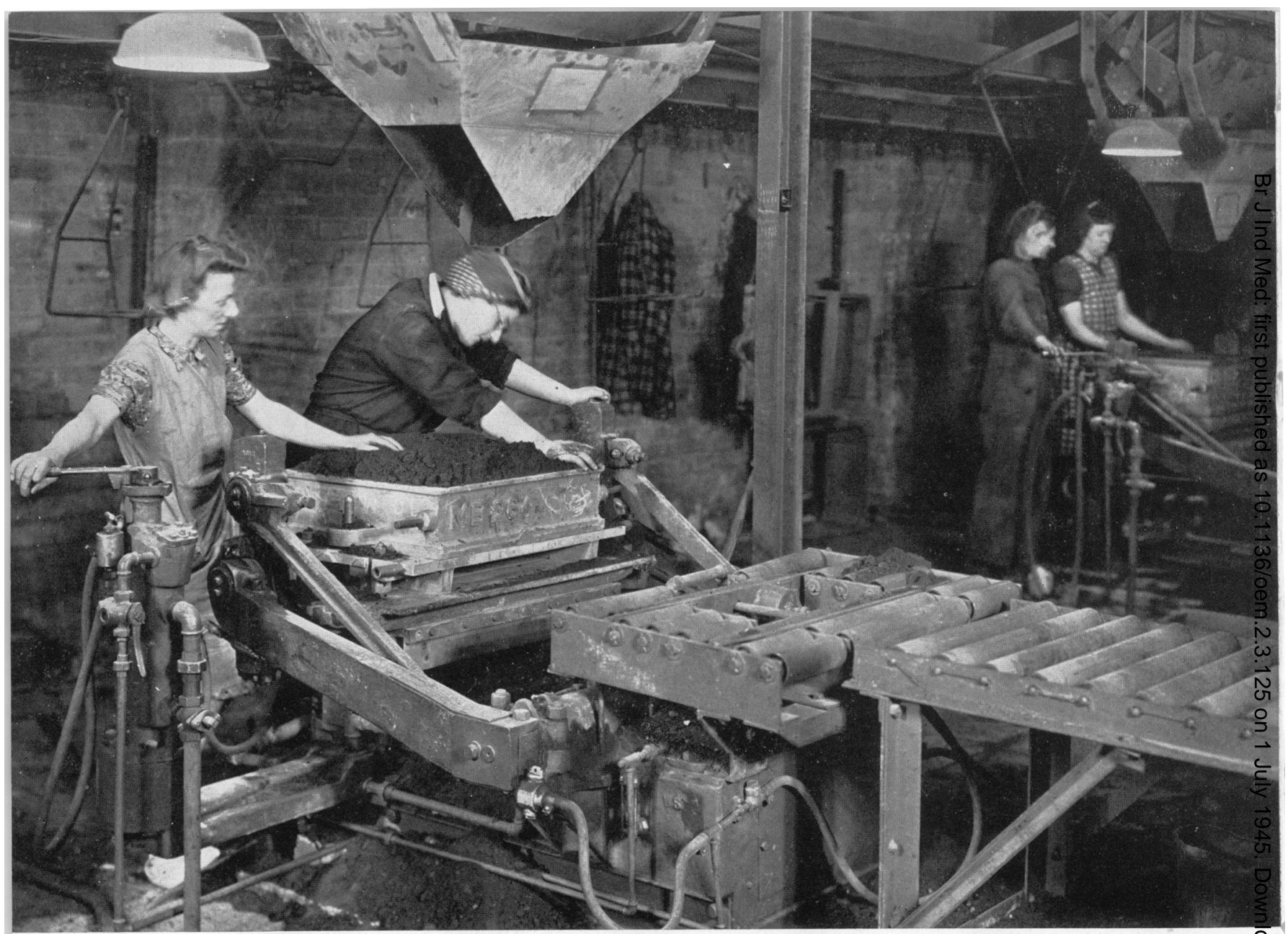

FIG. 8 (above).-Moulding machines and conveyor system for moulds.

FIG. 9 (below).-Core making. Note absence of visible dust on clothes of operators.

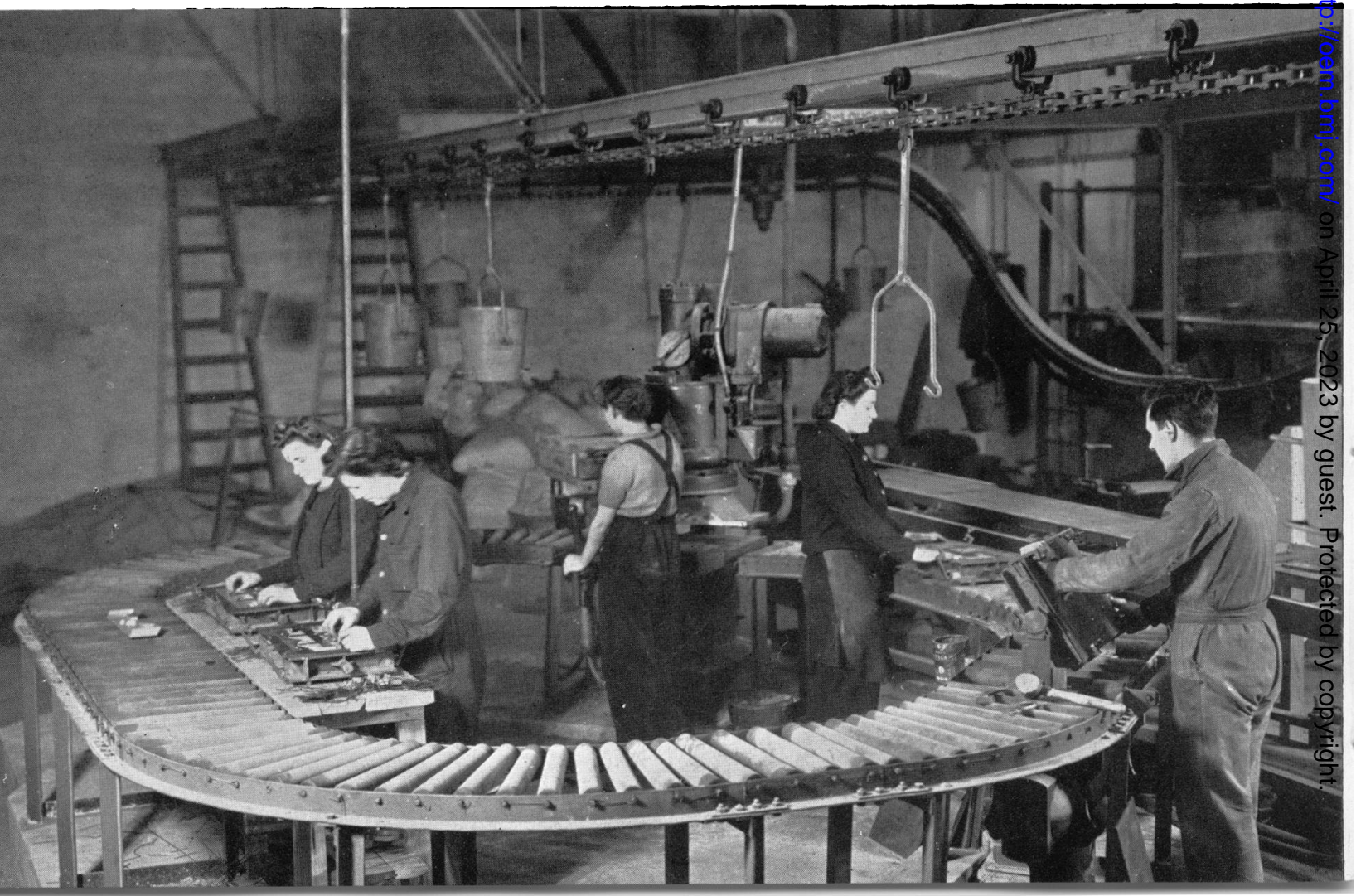


TABLE 7

OCCUPATIONAL HISTORY AND LUNG CHANGES AMONG 60 FOUNDRY WORKERS

\begin{tabular}{|c|c|c|c|c|c|c|}
\hline $\begin{array}{l}\text { Case } \\
\text { No. }\end{array}$ & Age & $\begin{array}{l}\text { No. of } \\
\text { years } \\
\text { engaged in } \\
\text { Foundry } \\
\text { work }\end{array}$ & Previous employment in other industry & $\begin{array}{l}\text { Principal occu- } \\
\text { pation while } \\
\text { employed in } \\
\text { Foundry }\end{array}$ & $\begin{array}{l}\text { Present occupa- } \\
\text { tion and how } \\
\text { long }\end{array}$ & $\begin{array}{l}\text { X-ray } \\
\text { Class* }\end{array}$ \\
\hline $\begin{array}{l}486 \\
403 \\
419\end{array}$ & $\begin{array}{l}46 \\
24 \\
24\end{array}$ & $\begin{array}{l}21 \\
9 \\
4 \frac{1}{2}\end{array}$ & $\begin{array}{c}\text { 'Nil. } \\
\text { 'Nil. } \\
\text { Cutting silk from bobbins. }\end{array}$ & $\begin{array}{l}\text { Fettling. } \\
\text { Moulding. } \\
\text { Moulding. }\end{array}$ & $\begin{array}{l}\text { Fettling } 21 \text { years. } \\
\text { Core shop } 5 \text { years. } \\
\text { Moulding }\end{array}$ & $\begin{array}{l}\text { III } \\
\text { I } \\
\text { II }\end{array}$ \\
\hline 556 & 54 & 5 & $\begin{array}{l}\text { Pottery: on clay modelling wheel } 13 \\
\text { years; H.M. Forces } 2 \text { years; colliery: } \\
\text { weighing coal } 20 \text { years. }\end{array}$ & Sand drier. & $\begin{array}{l}\text { Sand drier } \\
5 \text { years. }\end{array}$ & II + \\
\hline $\begin{array}{l}555 \\
518\end{array}$ & 48 & 24 & Nil. & Moulding. & Core Shop. & II \\
\hline 518 & 47 & 12 & $\begin{array}{l}\text { Acetylene burning, Constructional Eng. } \\
\text { Shop; colliery roads } 2 \text { years; coal- } \\
\text { getting } 6 \text { years. }\end{array}$ & Cupola Works. & $\begin{array}{l}\text { Cupola Works } \\
12 \text { years. }\end{array}$ & II \\
\hline $\begin{array}{l}401 \\
479\end{array}$ & $\begin{array}{l}23 \\
30\end{array}$ & $\begin{array}{l}8 \\
4\end{array}$ & $\begin{array}{l}\text { Pit Bank } 1 \text { year. } \\
\text { Iron rolling mills } 11 \text { years; Celanese } \\
2 \frac{1}{2} \text { years. }\end{array}$ & $\begin{array}{l}\text { Moulding. } \\
\text { Moulding. }\end{array}$ & $\begin{array}{l}\text { Moulding } 8 \text { years. } \\
\text { Moulding. }\end{array}$ & II \\
\hline 428 & 24 & 6 & Pit 10 weeks. & $\begin{array}{l}\text { Mechanized Sand } \\
\text { Plant. }\end{array}$ & $\begin{array}{l}\text { Mechanized Sand } \\
\text { Plant } 6 \text { years. }\end{array}$ & III \\
\hline 410 & 24 & 10 & Nil. & Moulding. & $\begin{array}{l}\text { Moulding } \\
10 \text { years. }\end{array}$ & II \\
\hline $\begin{array}{l}380 \\
433 \\
406\end{array}$ & $\begin{array}{l}21 \\
26 \\
42\end{array}$ & $\begin{array}{c}6 \\
12 \\
22 \frac{1}{2}\end{array}$ & $\begin{array}{l}\text { Errand boy } 1 \text { year. } \\
\text { Foundry crane driver } 6 \text { months. } \\
\text { Stringing bobbins } 6 \text { months. }\end{array}$ & $\begin{array}{l}\text { Moulding. } \\
\text { Moulding. } \\
\text { Moulding. }\end{array}$ & $\begin{array}{l}\text { Moulding } 6 \text { years. } \\
\text { Moulding } 12 \text { years. } \\
\text { Moulding } \\
22 \frac{1}{2} \text { years. }\end{array}$ & $\begin{array}{c}\text { II } \\
\text { II } \\
\text { II }+\end{array}$ \\
\hline 360 & 18 & 2 & $\begin{array}{l}\text { Pipe making: pneumatic hammer driver } \\
1 \text { year; pit bank } 1 \text { year. }\end{array}$ & Moulding. & Moulding 1 year. & II \\
\hline $\begin{array}{l}385 \\
373 \\
494 \\
368\end{array}$ & $\begin{array}{l}20 \\
23 \\
23 \\
17\end{array}$ & $\begin{array}{l}5 \\
7 \\
8 \\
1\end{array}$ & $\begin{array}{l}\text { Sand mixer } 1 \text { year; shop } 1 \text { year. } \\
\text { Dismantling cases. } \\
\text { Nil. } \\
\text { Rivet carrier. }\end{array}$ & $\begin{array}{l}\text { Moulding. } \\
\text { Moulding. } \\
\text { Fettling. } \\
\text { General } \\
\text { labouring. }\end{array}$ & $\begin{array}{l}\text { Moulding } 4 \text { years. } \\
\text { Moulding } 7 \text { years. } \\
\text { Fettling } 8 \text { years. } \\
\text { General labourer } \\
1 \text { year. }\end{array}$ & $\begin{array}{c}\text { II } \\
\text { III } \\
\text { II } \\
\text { I }\end{array}$ \\
\hline 415 & 43 & 21 & $\begin{array}{l}\text { Colliery loader } 3 \text { years; textile factory } \\
2 \text { years; labourer } 2 \text { years. }\end{array}$ & Moulding. & $\begin{array}{l}\text { Moulding } \\
19 \text { years. }\end{array}$ & III \\
\hline 537 & 65 & 3 & $\begin{array}{l}\text { Colliery: ganging } 6 \text { years; loading } 10 \\
\text { years. Contractor } 30 \text { years. Navy } \\
4 \text { years. }\end{array}$ & Labourer. & Labourer 3 years. & I \\
\hline 558 & 55 & 10 & $\begin{array}{l}\text { Colliery: ganging } 4 \text { years; loading then } \\
\text { getting coal for } 27 \text { years. }\end{array}$ & Labourer. & Sand Mixer. & II \\
\hline 534 & 40 & 8 & $\begin{array}{l}\text { Roadman } 3 \text { years; iron rolling mills. } \\
\text { apprentice fitter in Canadian foundry } \\
7 \text { years. }\end{array}$ & Fitter. & Fitter 8 years. & II \\
\hline 525 & 40 & 12 & Colliery surface work 14 years. & Labourer. & $\begin{array}{l}\text { General labourer, } \\
\text { night work, } 12 \\
\text { years. }\end{array}$ & II \\
\hline $\begin{array}{l}550 \\
548\end{array}$ & $\begin{array}{l}58 \\
40\end{array}$ & $\begin{array}{r}44 \\
2\end{array}$ & $\begin{array}{l}\text { Nil. } \\
\text { Colliery: coal face getting coal } 23 \text { years. } \\
\text { Night porter } 5 \text { years. A.R.P. Warden }\end{array}$ & $\begin{array}{l}\text { Every job in turn. } \\
\text { Labourer. }\end{array}$ & $\begin{array}{l}\text { Casting. } \\
\text { Night labourer } \\
2 \text { years. }\end{array}$ & $\begin{array}{l}\text { II } \\
\text { III }\end{array}$ \\
\hline 532 & 40 & 8 & $\begin{array}{l}2 \text { years. } \\
\text { Colliery: surface work } 1 \text { year; roads } \\
13 \text { years. Bricklayer's labourer } 5 \\
\text { years. Foundry labourer } 1 \text { year. }\end{array}$ & Cupola charger. & $\begin{array}{l}\text { Copula charger } \\
7 \text { years. }\end{array}$ & II \\
\hline 515 & 47 & 2 & $\begin{array}{l}\text { years. } \\
\text { Foundry labourer } 1 \text { year. } \\
\text { Colliery: surface work } 1 \text { year. H.M. } \\
\text { Forces } 4 \text { years. Blast furnace } 28 \\
\text { years. }\end{array}$ & Cupola. & Cupola. & II \\
\hline 757 & 62 & 10 & $\begin{array}{l}\text { years. } \\
\text { Pottery: making bottles } 1 \text { year. Col- } \\
\text { liery: pony driver } 30 \text { years. Con- } \\
\text { structional eng., carrying iron. }\end{array}$ & Cupola bank. & Sweeping up. & II \\
\hline $\begin{array}{l}593 \\
476\end{array}$ & $\begin{array}{l}65 \\
38\end{array}$ & $\begin{array}{r}30 \\
3\end{array}$ & $\begin{array}{l}\text { Colliery: firing boilers. } \\
\text { Sharpening pencils } i \text { year. Confec- }\end{array}$ & Moulding. & Moulding 30 years. & II \\
\hline & & & $\begin{array}{l}\text { tioner } 8 \text { years. Labourer on camp } \\
\text { construction } 1 \text { year. }\end{array}$ & Grinding. & Grinding. & II \\
\hline $\begin{array}{l}459 \\
528\end{array}$ & $\begin{array}{l}21 \\
57\end{array}$ & $\begin{array}{l}6 \\
3\end{array}$ & $\begin{array}{l}\text { Nil. } \\
\text { Surveyor's depot } 13 \text { years. H.M. } \\
\text { Forces } 4 \text { years. Colliery surface } 22 \text { years. }\end{array}$ & $\begin{array}{l}\text { Core shop. } \\
\text { Labourer. }\end{array}$ & $\begin{array}{l}\text { Cores } 6 \text { years. } \\
\text { Night labourer } \\
3 \text { years. }\end{array}$ & $\begin{array}{l}\text { II } \\
\text { II }\end{array}$ \\
\hline 477 & 44 & 4 & $\begin{array}{l}\text { Labourer } 1 \text { year. Colliery: coal face } \\
25 \text { years. }\end{array}$ & Moulding. & Moulding 4 years. & II \\
\hline
\end{tabular}

* The method used for classification of the radiological appearances has been:

Class I.- Normal lung. Class II.-Increased markings but not beyond normal limits for a town dweller $(+$ indicates excessive markings). Class III.-Early reticulation. Class IV.-First stage silicosis. Class V. - Second stage silicosis. Class VI. - Third stage silicosis. 
TABLE 7.-continued

\begin{tabular}{|c|c|c|c|c|c|c|}
\hline $\begin{array}{l}\text { Case } \\
\text { No. }\end{array}$ & Age & $\begin{array}{l}\text { No. of } \\
\text { years } \\
\text { engaged in } \\
\text { Foundry } \\
\text { work }\end{array}$ & Previous employment in other industry & $\begin{array}{l}\text { Principal occu- } \\
\text { pation while } \\
\text { employed in } \\
\text { Foundry }\end{array}$ & $\begin{array}{l}\text { Present occupa- } \\
\text { tion and how } \\
\text { long }\end{array}$ & $\begin{array}{l}\text { X-ray } \\
\text { Class* }\end{array}$ \\
\hline 641 & 64 & 33 & $\begin{array}{l}\text { Colliery: coal face } 6 \text { years. H.M. } \\
\text { Army } 4 \text { years. }\end{array}$ & Moulding. & Moulding & II \\
\hline $\begin{array}{l}611 \\
544\end{array}$ & $\begin{array}{l}27 \\
46\end{array}$ & $\begin{array}{r}10 \\
5\end{array}$ & $\begin{array}{l}\text { Foundry: pipe making } 2 \text { years. } \\
\text { Colliery: blacksmith } 2 \text { years. Timber- } \\
\text { ing, dattling } 18 \text { years. Colliery black- } \\
\text { smith } 2 \text { years. Foundry blacksmith } \\
2 \text { years. Air Ministry } 6 \text { months. }\end{array}$ & $\begin{array}{l}\text { Cores. } \\
\text { Fettling. }\end{array}$ & $\begin{array}{l}\text { Cores } 10 \text { years. } \\
\text { Fettler } 3 \text { years. }\end{array}$ & II \\
\hline 526 & 57 & 25 & $\begin{array}{l}\text { Stable boy and butler valet } 10 \text { years. } \\
\text { Great War } 6 \text { years. Boilers } 12 \text { years. }\end{array}$ & Stripper. & Stripper 13 years. & II \\
\hline 487 & 36 & 21 & $\begin{array}{l}\text { Foundry fitter } 6 \text { years. Celanese: bob- } \\
\text { bin winding } 1 \text { year. }\end{array}$ & Fettling. & $\begin{array}{l}\text { Fettling and grind- } \\
\text { ing } 21 \text { years. }\end{array}$ & III \\
\hline 609 & 20 & 6 & Nil. & Moulding. & $\begin{array}{l}\text { Moulding and } \\
\text { slingers } 6 \text { years. }\end{array}$ & I \\
\hline $\begin{array}{l}562 \\
556\end{array}$ & $\begin{array}{l}60 \\
60\end{array}$ & $\begin{array}{r}40 \\
6\end{array}$ & $\begin{array}{l}\text { Stone breaker } 1 \text { year. } \\
\text { Farm labourer and colliery loader } 5 \\
\text { years. Labourer, furnace man. }\end{array}$ & $\begin{array}{l}\text { Moulder. } \\
\text { Labourer. }\end{array}$ & $\begin{array}{l}\text { Labourer } 6 \text { years. } \\
\text { Labourer } 6 \text { years. }\end{array}$ & III \\
\hline 497 & 34 & 13 & Bricklayer 5 years. & Cupola repairs. & $\begin{array}{l}\text { Cupola repairs } \\
7 \text { years. }\end{array}$ & II \\
\hline $\begin{array}{l}489 \\
406\end{array}$ & $\begin{array}{l}24 \\
24\end{array}$ & $9 \frac{1}{2}$ & $\begin{array}{l}\text { Foundry } 1 \frac{1}{2} \text { years. Hosiery mill. } \\
\text { Stripping bobbins } 6 \text { months. }\end{array}$ & $\begin{array}{l}\text { Fettling. } \\
\text { Moulding. }\end{array}$ & $\begin{array}{l}\text { Fettling } 8 \text { years. } \\
\text { Moulding } \\
10 \text { years. }\end{array}$ & II \\
\hline $\begin{array}{l}385 \\
367\end{array}$ & $\begin{array}{l}21 \\
41\end{array}$ & $\begin{array}{r}5 \\
20\end{array}$ & $\begin{array}{l}\text { Foundry: sand mixer } 1 \text { year. } \\
\text { Cotton mill: cleaner } 3 \text { years. Colliery: } \\
\text { ganging } 2 \text { years; stall } 3 \text { years. Foundry } \\
\text { labourer } 2 \text { years. }\end{array}$ & $\begin{array}{l}\text { Moulding. } \\
\text { Moulding. }\end{array}$ & $\begin{array}{l}\text { Moulding } 4 \text { years. } \\
\text { Moulding } \\
18 \text { years. }\end{array}$ & III \\
\hline 591 & 62 & 47 & All jobs in iron foundry. & Loam moulding. & $\begin{array}{l}\text { Loam moulding } \\
30 \text { years. }\end{array}$ & III \\
\hline 595 & 54 & 41 . & Sand mixing and core making. & Casting various. & $\begin{array}{l}\text { Loam moulding } \\
20 \text { years. }\end{array}$ & II \\
\hline 594 & 51 & 40 & Sand moulding $3 \frac{1}{2}$ years. & Loam moulding. & $\begin{array}{l}\text { Loam moulding } \\
8 \text { years. }\end{array}$ & $\mathrm{II}+$ \\
\hline 615 & 15 & $\begin{array}{l}11 \\
\text { months }\end{array}$ & Nil. & $\begin{array}{l}\text { Core making } \\
6 \text { months. }\end{array}$ & $\begin{array}{l}\text { Loam moulding } \\
5 \text { months. }\end{array}$ & $\mathbf{I}$ \\
\hline 614 & 38 & $23 \frac{1}{2}$ & $\begin{array}{l}\text { Iron foundry: pattern shop } 2 \frac{1}{2} \text { years; } \\
\text { core making and moulding } 6 \frac{1}{2} \text { years. }\end{array}$ & Core making. & $\begin{array}{l}\text { Core making } \\
17 \text { years }\end{array}$ & I \\
\hline $\begin{array}{l}619 \\
623 \\
622\end{array}$ & $\begin{array}{l}34 \\
29\end{array}$ & $\begin{array}{l}20 \\
15 \\
16\end{array}$ & Farm labourer 1 year. & Moulding. & Moulding 20 years. & II \\
\hline 633 & 33 & 16 & Labourer 1 year. Pipe foundry $2 \frac{1}{2}$ years. & $\begin{array}{l}\text { General } \\
\text { labouring. }\end{array}$ & $\begin{array}{l}\text { Odd jobs, but } \\
\text { mostly mould- } \\
\text { ing } 13 \frac{1}{2} \text { years. }\end{array}$ & III \\
\hline 612 & 26 & 10 & $\begin{array}{l}\text { Turning shop slinger in foundry } 9 \\
\text { months. }\end{array}$ & Core making. & $\begin{array}{l}\text { Core making } \\
10 \text { years. }\end{array}$ & II \\
\hline $\begin{array}{l}632 \\
629\end{array}$ & $\begin{array}{l}58 \\
46\end{array}$ & $\begin{array}{l}42 \\
23\end{array}$ & $\begin{array}{l}\text { Railway porter } 9 \text { years. } \\
\text { Core making } 2 \text { years. Ships' stoker in } \\
\text { summer, lumberjack in winter ( } 6 \text { years } \\
\text { in Canada). }\end{array}$ & $\begin{array}{l}\text { Moulding. } \\
\text { Moulding. }\end{array}$ & $\begin{array}{l}\text { Moulding } 42 \text { years. } \\
\text { Moulding. }\end{array}$ & III \\
\hline $\begin{array}{l}626 \\
628\end{array}$ & $\begin{array}{l}68 \\
53\end{array}$ & $\begin{array}{l}53 \\
39\end{array}$ & $\begin{array}{c}\text { Colliery dattling } 1 \text { year. } \\
\text { Nil. }\end{array}$ & $\begin{array}{l}\text { Moulding. } \\
\text { Moulding. }\end{array}$ & $\begin{array}{l}\text { Moulding } 53 \text { years. } \\
\text { Moulding } 39 \text { years. }\end{array}$ & II \\
\hline
\end{tabular}


TABLE 8

X-RAY SURVEY OF WORKERS AT BUTTERLEY FOUNDRY

Total number examined $=60$. Average age 29 years.

Part One. Showing number examined in different age groups.*

\begin{tabular}{|c|c|c|c|c|c|c|c|c|}
\hline Age & $\underset{20}{\text { under }}$ & $21-30$ & $31-40$ & $41-50$ & $51-60$ & $\begin{array}{c}60 \\
\text { plus }\end{array}$ & Total & $\begin{array}{c}\text { Total } \\
\text { showing } \\
\text { dust } \\
\text { changes }\end{array}$ \\
\hline Fettlers & - & $\mathrm{x}_{2}^{\mathrm{x}^{2}}$ & 1 & 2 & - & - & 5 & 2 \\
\hline Moulders & 2 & $x_{12}$ & $x_{4}$ & $\mathrm{x}^{\mathrm{xx}}$ & $x_{5}$ & $x_{5}$ & 31 & 8 \\
\hline Others .. & 1 & $x_{4}$ & $x_{7}$ & 3 & $x_{7}$ & 2 & 24 & 3 \\
\hline 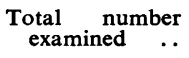 & 3 & 18 & 12 & 8 & 12 & 7 & 60 & - \\
\hline $\begin{array}{c}\text { Total number } \\
\text { showing dust } \\
\text { changes in age } \\
\text { groups }\end{array}$ & - & 3 & 3 & 4 & 2 & 1 & - & 13 \\
\hline
\end{tabular}

TABLE 9

\section{X-RAY SURVEY OF WORKERS AT BUTTERLEY
FOUNDRY}

Total number examined $=60$. Average age $=29$ years. Part Two. Showing length of exposure to dust.*

\begin{tabular}{|c|c|c|c|c|c|c|c|c|}
\hline $\begin{array}{l}\text { Length of ex- } \\
\text { posure. }\end{array}$ & $\begin{array}{l}\text { under } \\
2 \text { yrs. }\end{array}$ & $3-5$ & 6-10 & $11-15$ & $15-20$ & $21-25$ & $5 \mid 26-30$ & $\begin{array}{c}\text { over } \\
30\end{array}$ \\
\hline Fettlers & - & 1 & - & - & - & $x 2 x$ & - & - \\
\hline Moulders & $x_{1}$ & $x_{6}$ & ${ }_{6}^{x}$ & $\begin{array}{l}x \\
2\end{array}$ & $\begin{array}{l}\mathbf{x} \\
3\end{array}$ & $\mathrm{x}_{4} \mathrm{x}$ & 1 & $\mathrm{xx}_{10}$ \\
\hline Others .. & $x_{1}$ & 5 & $\mathrm{xx}_{9}$ & 4 & - & 3 & - & - \\
\hline $\begin{array}{l}\text { Total number } \\
\text { showing dust } \\
\text { changes ac- } \\
\text { cording to } \\
\text { length of ex- } \\
\text { posure to dust }\end{array}$ & 1 & 1 & 3 & 1 & 1 & 4 & - & 2 \\
\hline $\begin{array}{c}\text { Total number } \\
\text { examined }\end{array}$ & 2 & 12 & 17 & 6 & 3 & 9 & 1 & 10 \\
\hline
\end{tabular}

\section{Skin Affections}

Most of the skin cases were of the septic type, usually the result of mild staphylococcal infection, and the only inference which may be drawn from them is that probably the fine dust makes its way through a break in the continuity of the skin rather easily and carries the common bacteria with it.

Although no cases occurred in the period under review there is nevertheless a real risk of occupational dermatitis in foundry work. This generally shows itself in the form of the skin irritation seen in many other industries. In our experience dermatitis occurs most commonly amongst core makers in whom the irritation appears to be due to the oil used in the core sand, but other workers in the foundry are not immune and may be affected by sand alone. Another type of dermatitis is occasionally seen similar to that occurring in the coal miner and affecting the axillae and groins and * $x$ indicates a worker showing dust changes in the lung on $x$-ray
examination. other parts of the body where much friction and sweating take place. This is in effect an intertrigo.

\section{Rheumatic Disease}

Until the causes of rheumatism are more definitely established it is not possible to give exact reasons for the high incidence of rheumatic disease in foundrymen; all that can be said is that the disease is very prevalent amongst workers exposed to sudden changes of temperature and strains on the muscles from heavy occupations.

Exposure to heat does not cause as much trouble as might be expected. Heat cramps are uncommon but not unknown; vague muscular pains may be due to salt depletion but Fantus' test for chlorides (War Office, 1943) in the urine gives an easy means of determining whether a fall below the dangerous excretion level of $3 \mathrm{~g}$. in the twenty-four hours has taken place.

\section{Accidents}

It has already been seen that the Foundries had fewer accidents and much less lost time due to this cause than the Constructional Department. The accidents in the Foundries were not on the whole of a serious nature and surprisingly few burns caused trouble. Indeed, burns are much less common in foundry practice than might have been anticipated.

\section{Preventive Measures}

\section{Pre-employment Examination}

In view of the relatively high risk of disease occurring in the foundryman, a complete physical examination, including $x$-ray of the chest, should be carried out on all those entering the industry (Lancet, 1938, 2, 629).

A history of respiratory disease is important, and taken in conjunction with $\mathrm{x}$-ray findings may be enough to exclude an applicant from foundry work. Even in the absence of an anomalous x-ray one would hesitate to allow a person with a history of recurrent bronchitis to work in the foundry. X-ray evidence of tuberculosis, either active or quiescent, or of fibrosis of the lungs, is an absolute bar to foundry work. Those with infected tonsils or rhinitis, either hypertrophic or atrophic, do not as a rule do well in foundry work as they are liable to exacerbations of tonsillitis or rhinitis, often associated with sinusitis. They are better out of the foundry, but it is permissible to give them a trial.

Workers with perforated ear drums should be rejected, both on account of the risk of exacerbation of otitis media and also because they do not stand up well to the noisy conditions of machine moulding. People with previous history of skin disease or with actual dermatitis should be excluded, as also should those with very dry skins or those who tend to sweat unduly.

The value of the pre-employment examination cannot be rated too highly; it is of far more importance than any subsequent examination, for if it is 
carried out conscientiously the greater number of those who are likely to break down under foundry conditions can be excluded. This is not to say that periodic examinations are not required, for it is agreed that they are desirable under any circumstances. Time does not allow of the periodic examination of employees in a large organization as frequently as one would wish, but we are aiming at a quarterly check on young persons up to 18 years of age with annual x-ray, and an examination, including x-ray, at five-year intervals for the older workers. Admittedly this is not ideal, but it should be sufficient to serve as a check on the dust hazard.

\section{Building a New Foundry}

Modern methods of construction and ventilation can greatly improve the conditions of the foundry. Noise and vibration can be reduced enormously, and a less vitiated atmosphere obtained. Proper cloak-room and washing facilities, including bathing facilities, are important and should receive as high a priority in consideration as the production part of the foundry.

\section{The Existing Foundry}

In the already existing foundry, as in other shops, the attention of the management should be directed to defects in lighting and ventilation; but heating, floors, and house-keeping are most difficult problems. In winter weather the shop is liable to be cold in the morning before casting begins and it is difficult to see how this can be overcome without an air conditioning system.

Concrete floors are desirable as they are comparatively easy to keep clean, but they are satisfactory only in the case of the mechanized unit where pouring takes place at a definite point and there is no great risk of spilling metal on to the floor with fragmentation of the concrete. It is quite otherwise, however, in the foundry dealing with large castings or where pouring is done with the boxes on the floor, although concrete walk-ways may be possible. Good house-keeping is easier where there is a concrete floor but is by no means so easy in the foundry as in some other shops.

\section{Baths}

It has been shown that rheumatism takes a high place amongst the hazards of the foundry, and Osgood (1932) after emphasizing the importance of proper environmental conditions both at work and away from it in the prevention of this disease, stresses the necessity for providing shower baths at work. The provision of baths is no less necessary in order to reduce the high incidence of skin conditions, and there is no doubt that changing rooms and shower baths on the principle of pit-head baths are urgently needed in the foundry industry. Baths are not sufficient in themselves and frequent change and washing of working clothes are required in order to control skin conditions.

Bathing facilities will not only improve the health of the worker in the foundry in an overt manner, but also indirectly by enabling him to pass to and from his work as clean as any of his companions in less dirty trades and by so doing increase his selfrespect. Drinking water should be provided at suitable points and is best supplied by bubbler fountains. Salt tablets should be available if necessary for those exposed to excessive heat so that the risk of heat cramps may be minimized.

\section{Protective Equipment}

Hand leathers should be supplied to those handling rough castings, and all foundry workers should wear properly protected boots. Leather spats or spat leathers with strap fastenings should also be used to protect against splashes of molten metal. Aprons should be of asbestos or of material rendered fireproof by chemical means.

A proper eye-protective appliance must, of course, be provided for those exposed to the glare of furnaces and molten metal, and grinders require. goggles to prevent injury to the eyes from flying particles of metal and dust. Respirators are also needed for grinders, and they should also be worn by those engaged on dusty processes which cannot be kept properly under control such as the repair of cupola linings.

\section{Dust}

The main specific health risk of the iron foundry is the inhalation of free silica, and the substitution of an innocuous material for a harmful one is the best way in which to deal with any hazard. The use of olivine which is a mineral composed of magnesium and ferrous orthosilicate $\left(\mathrm{MgFe}_{2} \mathrm{SiO}_{4}\right)$ and which recent work (King and Rogers, 1945) has shown to have no fibrosis-forming effect on the lungs, has been suggested (Goldschmidt, 1938) as a practicable substitute for the sand used for the body of the moulds. Whether this substance proves to be technically satisfactory remains to be seen, but there is no possible justification for the use of a silica parting powder when equally effective non-siliceous powders are available; and this is largely true also of silica paint. As long as a sand containing free silica is in use in the foundry, dust control will remain vital, the principal danger points being the knock-out, stripping, fettling and grinding operations, including rumbling and blasting by means of wheelabrator, sand-blasting or other methods.

The regulations regarding sand-blasting render the process reasonably safe and the enclosed types of wheelabrator or rumbler with exhaust extraction are also satisfactory, provided that the extraction system works efficiently. Grinding carried out in accordance with the regulations also meets the case, but the knock-out and fettling operations are not governed by regulations and require special consideration. In the case of the knock-out the diffculty can be largely overcome by drawing the dust downwards through the grating by artificial means 
(see fig. 10) while the fettling of small castings can be done in a similar manner on a mild steel bench constructed on the grating principle and fitted with an exhaust system.

The larger casting presents special difficulties although a pneumatic chisel fitted with a small hood and flexible duct has been tried with encouraging results. Tests made in the United States of America suggest that there is no risk of inhalation of dust in the operation of hydro-blasting, and in a foundry in this country where the plant is in use the atmosphere certainly seemed very clear. Meanwhile the fettler carrying out this kind of work should wear suitable protective clothing (see fig. 13).

Although the greater amount of dust and fume in the atmosphere of the mechanized foundry can be kept under control by suitable methods of exhaust ventilation, installation of the hydro-blast system of cleaning castings should be carefully considered in all large foundries. Increased mechanization also has the merit that it reduces the amount of weight lifting, for in far too many foundries weights greatly in excess of the generally accepted standards are lifted all day and every day.

\section{Acknowledgments}

Our thanks are due to Mr. G. Walker, manager of the foundries of the Butterley Company, Ltd., for much help in the description of the technical processes; to Mr. John Gardom for the drawings reproduced in figs. 1 and 2; and to Messrs. Pneulec, Limited, for the photographs illustrating foundry methods. We must also thank Miss Pullon, Secretary of the Medical Department, for her invaluable assistance throughout the preparation of this paper.

\section{Summary}

A brief description is given of modern ironfounding methods.

Environmental studies were carried out in two foundries employing over 200 workers. These studies included a survey of ventilation and heating, and the dust hazard.

To assess the dust hazard in a foundry knowledge is required of $(a)$ the dust concentration in the work atmosphere, $(b)$ the duration of work spells, $(c)$ the chemical composition of inhaled dust, and $(d)$ its particle-size frequency.

In this survey it is shown that fettlers of medium and large castings have the dustiest occupation in the foundry. Chemical analysis shows that the dust here consists largely of silica particles. In the foundries under consideration it is estimated that the silica hazard of the fettler of large castings is fifty times that of a worker in the general body of the foundry; medium fettling represents a nine times greater hazard; and pneumatic mould-filling and shaking-out no more than five times.

Workers in the core shop are exposed to a minimal dust hazard because of the nature of the material used.

Routine control of atmospheric pollution in a foundry is essential. The simplest way of doing this is by mass concentration estimations of airborne dust at breathing height.

Sickness and accident rates among the foundry workers were compared with those in another department (constructional).

The number of cases of respiratory disease in the foundries was less, although the average number of days lost per case was higher. Sixty foundrymen had chest x-ray examination. While 21 per cent. of these showed some evidence of 'dust change' in the lung ( 40 per cent. of fettlers being affected), no case of silicosis was found, even in its early stages.

Affections of the skin were greater in the 200 foundry than in the constructional department, most of them being mild staphylococcal infections. Dermatitis in the foundry occurs most commonly among core-makers.

The incidence of rheumatic disease was greater among the foundrymen than among the workers in the constructional department. No definite reasons can be given for this.

Among foundrymen heat cramps are uncommon but not unknown.

Accidents causing injury were fewer and caused much less lost time in the foundries. Burns are less common in foundry practice than was anticipated.

Preventive measures against accident and ill-health are $(a)$ pre-employment medical examination, including chest x-ray; (b) improvement of ventilation by modern construction methods; (c) proper cloak-room, washing and bathing facilities; $(d)$ attention to floors; $(e)$ by adequate protective equipment for the individual worker and $(f)$ prevention of fumes and dust by alteration in materials where possible, by increasing mechanized methods of production, e.g. introducing the hydro-blast system, and by good general house-keeping.

\section{REFERENCES}

Campbell, J. A. (1943). Brit. med. J., 1, 179.

Denny, J., Robson, W., and Irwin, D. (1937). Canad. med. Ass. J.,

Gardner, L. U., Morris, D., and Delahant, A. B. (1944). J. industr. Hyg., 26, 7.

Goldschmidt, V. M. (1938). Industr. Eng. Chem., 30, 27

Industrial Environment and Health. Internat. Lab. Off., Geneva (1936), 124.

Instit. of Mining and Metallurgy. Papers on Dust Sampling Investigations. London, 1938, 145.

King, E. J., and Rogers, N. (1945). Proc. roy. Soc. Med. (in the press).

Lowrie Fairs, G. (1944). Chem. Ind., 62, 374.

McConnel, W. J., and Fennel, J. W. (1934). J. industr. Hyg., 16, 227. Monmouthshire and S.W. Coal Owners Ass. 7th Rep. Coal Dust Res. Com. (1942). Experience gained in sampling.

Osgood, R. B. (1932). New Engl. J. Med., 206, 1.

Registrar-General's Decennial Supplement, England and Wales, 1931. Part IIA: Occupational Mortality (1938). H.M.S.O., Lond.

Report of the Committee appointed to consider the Problem of Dust in Steel Foundries (1944). H.M.S.O., Lond.

Ross, A. A., and Shaw, N. ${ }^{-H}$. (1943). Dust Hazards in Australian Foundries. Tech. Rep. No. 1, Dept. Labour and National Service, Commonwealth of Australia.

Sander, O. A. (1938). Amer. J. publ. Hlth., 28, 601.

Silicosis in Foundry Workers (1938). Leading Article, Lancet, 2, 629. War Office: Army Med. Dept. Bulletin No. 23 (1943). A Test for Salt Depletion. 